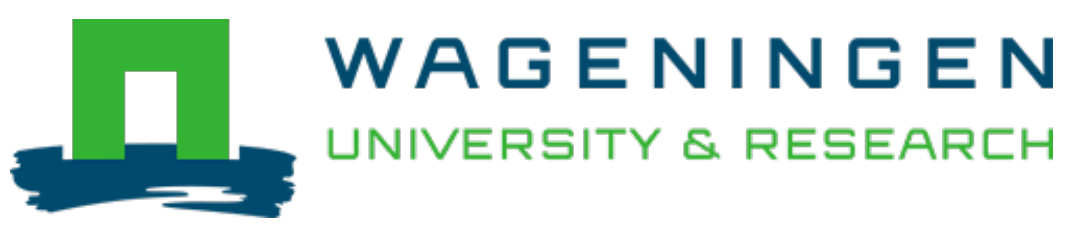

\title{
Urbanizing rural waters : Rural-urban water transfers and the reconfiguration of hydrosocial territories in Lima
}

\author{
Political Geography \\ Hommes, Lena; Boelens, Rutgerd \\ https://doi.org/10.1016/j.polgeo.2016.12.002
}

This publication is made publicly available in the institutional repository of Wageningen University and Research, under the terms of article $25 \mathrm{fa}$ of the Dutch Copyright Act, also known as the Amendment Taverne. This has been done with explicit consent by the author.

Article 25 fa states that the author of a short scientific work funded either wholly or partially by Dutch public funds is entitled to make that work publicly available for no consideration following a reasonable period of time after the work was first published, provided that clear reference is made to the source of the first publication of the work.

This publication is distributed under The Association of Universities in the Netherlands (VSNU) 'Article $25 \mathrm{fa}$ implementation' project. In this project research outputs of researchers employed by Dutch Universities that comply with the legal requirements of Article $25 \mathrm{fa}$ of the Dutch Copyright Act are distributed online and free of cost or other barriers in institutional repositories. Research outputs are distributed six months after their first online publication in the original published version and with proper attribution to the source of the original publication.

You are permitted to download and use the publication for personal purposes. All rights remain with the author(s) and / or copyright owner(s) of this work. Any use of the publication or parts of it other than authorised under article $25 \mathrm{fa}$ of the Dutch Copyright act is prohibited. Wageningen University \& Research and the author(s) of this publication shall not be held responsible or liable for any damages resulting from your (re)use of this publication.

For questions regarding the public availability of this publication please contact openscience.library@wur.nl 


\title{
Urbanizing rural waters: Rural-urban water transfers and the reconfiguration of hydrosocial territories in Lima
}

\author{
Lena Hommes ${ }^{\text {a, }}$, Rutgerd Boelens ${ }^{\text {a, b, c }}$ \\ ${ }^{a}$ Water Resource Management Group, Department Environmental Sciences, Wageningen University, P.O. Box 47, 6700 AA, Wageningen, The Netherlands \\ ${ }^{\mathrm{b}}$ CEDLA (Centre for Latin American Research and Documentation), University of Amsterdam, Roetersstraat 33, 1018 WB, Amsterdam, The Netherlands \\ ${ }^{c}$ Department Geography, Planning and International Development, University of Amsterdam, P.O. Box 15629, 1001 NC, Amsterdam, The Netherlands
}

\section{A R T I C L E I N F O}

Article history:

Received 10 March 2016

Received in revised form 3 December 2016

Accepted 6 December 2016

\section{Keywords:}

Water governance

Urbanization

Urban-rural relations

Hydrosocial territory

Water transfers

Hydropower

\begin{abstract}
A B S T R A C T
This article studies how urbanization processes and associated rural-urban water transfers in the Lima region (Peru) create water control hierarchies that align the municipal drinking water company, hydropower plants and rural communities on unequal positions. By scrutinizing the history of water transfers and hydropower development in the Lima region, the paper shows how imaginaries about the superiority of engineering, the need to generate electricity for national development, the backwardness of the 'land of lagoons' where water is diverted from, and about wished-for water abundance in Lima, all became manifested in hydraulic megaprojects. More than technical means to supply water to Lima City, these hydraulic grids, supported by legal, institutional and financial governance techniques; produce diverging material, social-symbolic and political effects for rural and urban water users. While the established system means water control and access for hydropower and drinking water companies, it implies dependence and/or exclusion from the benefits for rural communities. More specifically and beyond questions of outright water grabbing, perceived injustices involve the distribution of waterrelated benefits, loss of autonomy, and the socio-environmental impacts of territorial transformations.
\end{abstract}

(C) 2016 Elsevier Ltd. All rights reserved.

\section{Introduction - urbanization and urbanized waters}

The decision was made: change the geography and crush the high peaks of the strongest hydrological boundary line, to enrich the Santa Eulalia watershed from the virgin sources of Marcapomacocha, an extensive highland, full of wild waters and lagoons.

The battle in the dark tunnel, full of primordial smells set free by rock drills and dynamite, lasted fifty-six months. A tremendous, frightening battle against an enemy that wouldn't bow down: the water behaved in outright confrontation with those water seekers - a heroic deed by workers in the cordillera. (Hermann Buse in his book Huinco 200,000 KW (1965:87, 7) describing the construction of the first trans-Andean water transfer to Lima)

An emerging body of literature and public attention currently focuses on worldwide accelerating urbanization processes, everexpanding mega cities and the challenges posed. Concerns about

\footnotetext{
* Corresponding author.

E-mail addresses: lenaho@gmx.net (L. Hommes), Rutgerd.boelens@wur.nl (R. Boelens).
}

water and sanitation services in urban areas and equitable access figure prominently in scholarly literature and policy debate (e.g. Anand, 2011; Bakker, 2010; Banister \& Widdifield, 2014; Gandy, 2004; Meehan, 2013; Swyngedouw, 2004). Urbanization processes also lead to severe pressure on natural resources in surrounding rural areas, especially when resources such as water are not easily available in the cities themselves due to, for example, climatic conditions or high urban demands. As a response, numerous cities in different parts of the world implement largescale water transfers, diverting water from regions ever-further away in order to provide cities with additional water resources (e.g., Kaika, 2006; Molle \& Berkoff, 2006). While such water transfers may slake cities' thirst and, in some cases, also generate hydroelectricity, they raise major questions about sustainability, implications for rural areas and concerns of environmental justice between rural communities and expanding cities (e.g. Roa-García, 2014).

One remarkable case in which urban growth increases competition for water resources is Lima, the capital city of Peru, with around nine million inhabitants (Riveros, Germaná, \& Alvarez, 2014). Lima is home to one-third of Peru's total population, and the country's commercial, industrial and political centre. Situated in the coastal desert, the city's average annual precipitation is less 
than $10 \mathrm{~mm}$. This leads to heavy dependence for water supply from the nearby Andean mountain range and the three surrounding watersheds of the Chillón, Rímac and Lurín Rivers. In these watersheds water is also used for agriculture, industry, mining, hydropower and rural domestic uses, making water governance highly complex and contested (see for example Autoridad Nacional del Agua, 2010; Moreno \& Huerse, 2010). ${ }^{1}$

'Water scarcity' in Lima is in fact a human-produced and politically-decided phenomenon rather than natural, affecting different populations within the same city unevenly (Ioris, 2012, 2016). Some neighbourhoods' water abundance, squandering and over-allocation mean a lack of sufficient good-quality water in others (Miranda, Pfeffer, \& Baud, 2016). Around one million inhabitants who live in the poorest urban periphery have no access to safe drinking water provided by the city's Water and Sewage Company SEDAPAL (Servicio de Agua Potable y Alcantarillado de Lima). They rely on private water trucks charging extremely high prices for often contaminated water (Ioris, 2012; Schütze \& Robleto, 2009). This is a mockery, considering that richer areas of the city fill rooftop pools, and over-water big parks and golf courses, sometimes with drinking water (e.g., Ioris, 2012, 2016; Miranda et al., 2016).

Nevertheless, based on the imperative discourse that Lima generically needs more water, since the 1960s additional water resources have been transferred from the upper Mantaro watershed, a basin on the Amazon side of the Andes, to the Santa Eulalia watershed, which is a tributary to the Rímac River. While the first water transfer project was in fact implemented to provide extra water for electricity generation by numerous hydropower plants in the Rímac basin, Mantaro resources now supply a significant part of Lima's drinking water demands. There are currently three water transfer projects from the Mantaro watershed, called Marca I, III and IV, named after the first lagoon (Marcapomacocha) sending water to Lima. The lagoon of Marcapomacocha still collects and regulates water coming from the system of canals, tunnels and dammed lagoons that make up the three Marca projects. From Marcapomacocha, water is transported through a canal and a $10 \mathrm{~km}$ trans-Andean tunnel to the Santa Eulalia watershed (see Fig. 1 for an overview of project locations). The last water transfer project was inaugurated in 2012 by a public-private partnership between SEDAPAL and EPASA (Empresa Peruana de Aguas - Peruvian Water Company); analysed in the last part of this paper. Additional similar projects are planned for years to come so that large-scale water transfers will remain central to SEDAPAL's strategy to provide water for Lima (SEDAPAL, 2014).

Even though this complex infrastructure system plays a key role for water governance in the Lima region, very little is known about the history, mechanisms and interests that produced and maintain it. It is likewise unknown how the constructed hydraulic infrastructure reshapes hydrosocial territories in Lima's adjacent watersheds, impacting different water users' access and control over water resources and decision-making. This is striking and alarming, considering that water transfers and hydropower development which, in the case of Lima, go hand in hand - often have deep socioeconomic, political and ecological impacts (see for example Celio, Scott, \& Giordano, 2010; Duarte-Abadía, Boelens, \& RoaAvendaño, 2015; Showers, 2002).

\footnotetext{
1 Besides, groundwater from two aquifers constitutes an important additional water source for domestic as well as industrial users (Seifert, 2009). The estimated rate of extraction is around $13 \mathrm{~m}^{3} /$ second, which is considered "overexploitation" and which results in steadily decreasing groundwater levels (Seifert, 2009: 30); also partly due to an ineffective regulatory framework (Interview SEDAPAL, August 2015).
}

The aim of this paper, therefore, is twofold. First, we scrutinize the history of the water transfers and hydropower development in the Lima region and show how specific imaginaries became materialized in the infrastructure under study. By showing the power and concrete effects of imaginaries, we contribute to ongoing discussions about the conceptualization of hydrosocial territory with regards to its material, symbolic/discursive and cultural constitutions. Disclosing other legal and discursive mechanisms that have produced and supported infrastructure development until today will complement the historic analysis of imaginaries. Second, we focus on the effects this brings about, departing from our understanding of water transfers and hydropower structures as geographical forces that are physical, legal, symbolic as well as social in their effects. The central questions we thus answer are: How do accelerating urbanization processes drive the profound reshaping of rural-urban hydrosocial territories? How does this reshaping in the rural-urban interface affect different water user groups' access to and control over water resources?

The paper is based on research conducted during 2015 and early 2016, including extensive literature, newspaper and archival study; 43 in-depth interviews with key stakeholders in Lima, the Mantaro region and the Santa Eulalia watershed, as well as numerous field trips and participation in relevant events. This research was made possible by the International WaTERS Network and was embedded in ongoing activities of the Water Justice Alliance (Justicia Hídrica). ${ }^{2}$ A conceptual framework based on the emerging body of literature on hydrosocial territories and rural-urban relations is employed. Within the notion of hydrosocial territories, special attention is devoted to the multidimensionality of hydraulic infrastructure and the power of imaginaries. The next section will outline key aspects of this conceptual framework, followed by reconstructing the history of Lima's water and modernity dream. What follows is an analysis of current hydrosocial territory reconfiguration and the way it is underpinned by specific discourses and legal, political and financial arrangements. Next, resulting implications for different water user groups' access to and control over water resources will be examined for the case of the most recently implemented Marca Project (Marca IV - Huascacocha). The final section presents our conclusions.

\section{Hydrosocial territories and rural-urban water transfers}

Territories and related concepts have long been topic of thought in the field of political geography. With time, debates have moved away from associating territory technocratically and instrumentally with nation-state boundaries, towards regarding it as a concept that encompasses material, symbolic and functional aspects (Escobar, 2008; Hassner, 1997; Lefebvre, 1991). As Agnew (1994) and Elden (2010) discuss, territory is at once judicial, political, economic, social, cultural, affective and physical. Accordingly, legalpolitical and social institutions, cultural relations, ideas and practices as well as physical structures and the environment make up multi-scalar networks that form territory (Brenner, 1998; Doucette

\footnotetext{
2 Our position as researchers in the Lima basin is situated, in conceptual and political terms. Researchers cannot 'observe' social arrangements, norms and rights 'in action' without interpreting and, thus, using their defining power and network relations; taking a position is indispensable. We look in particular at how dignified and fair livelihood steadiness of Andean communities and families is threatened by (ab)use of power, internally and externally. This situated-ness is political in that we concentrate on the position of those with less clout in the water world. Situated (political geography and water governance) knowledge and analysis do not imply one-dimensional bias. As Haraway (1991) commented, the art of seeing well - and recognizing intrinsic distinctiveness and particularities - necessarily requires 'being located'.
} 




Fig. 1. Map of Lima's watersheds and hydraulic infrastructure in the Rímac and Mantaro watersheds, by the authors.

\& Lee, 2015; Jonas, 1994). Territories, procedural and interactional, evolve out of the power-laden encounter of, and negotiation between, different societal actors within the same time and space (Brighenti, 2010; Heynen \& Swyngedouw, 2003). Given that societal actors always have divergent ideas and interests about how space, people, nature and knowledges should be managed, the making of territory is a highly contested and always ongoing process. In line with scholarship that entwines notions of territory, conflicting imaginaries, statecraft and power we build on an embodied socio-material and political-ecological approach: "politically speaking, territory is the socio-materially constituted and geographically delineated organisation and expression of and for the exercise of political power" (Swyngedouw and Boelens, Forthcoming).

In our analysis of rural-urban water governance in Lima, we make contributions to the territory scholarship by bringing it into fruitful discussion with water governance politics scholarship, in particular through the concept of hydrosocial territories. Here, we draw particular attention to the ways in which imaginaries are more than merely symbolic or discursive aspects of territory but forces that become materialized in geographical projects and techno-political artefacts and grids. The materializations we focus on are hydraulic infrastructure. Coming forth from powerful imaginaries as well as associated institutions and discourses, hydraulic infrastructure is material, social and symbolic in its origins and its effects, constituting an important force in rural-urban dynamics and territory making in the Lima region. We thus combine conceptual bodies of thought about territories, imaginaries, socio-ecological systems and hydraulic infrastructure in the concept of hydrosocial territories. This then provides an insightful way for understanding territorial dynamics triggered by urbanization and associated demands for water and energy.

Hydrosocial territories are conceptualized as "the contested imaginary and socio-environmental materialization of a spatiallybound multi-scalar network in which humans, water flows, ecological relations, hydraulic infrastructure, financial means, legal-administrative arrangements and cultural institutions and practices are interactively defined, aligned and mobilized through epistemological belief systems, political hierarchies and naturalizing discourses" (Boelens, Hoogesteger, Swyngedouw, Vos, \& Wester, 2016:2). As compared to the related concepts of waterscapes (Baviskar, 2007; Budds \& Hinojosa-Valencia, 2012; Swyngedouw, 1999) and the hydrosocial cycle (Linton \& Budds, 2014; Swyngedouw, 2009), the notion of hydrosocial territories as contested imaginaries and their materializations helps understanding territorial diversity within a given time and space, featuring a multitude of actors with often diverging interests, territorial imaginaries and corresponding hydrosocial projects (Baletti, 2012; Barnes and Alatout, 2012; Hoogesteger, Boelens, \& Baud, 2016). This analytical focus shifts to emphasizing territorial diversity and struggles over territories as struggles over meaning, imaginaries and their realization (cf. Minca et al., 2015). The continuous 
reconfigurations of political geographies of water governance and socio-ecological relations are at the centre of attention (cf. GrundyWarr, Sithirith, \& Li, 2015), including governmentality endeavours, cultural politics, and overt and covert contestation and subaltern strategies (e.g., Boelens, 2014, 2015; Damonte-Valencia, 2015; Hommes, Boelens, \& Maat, 2016; Swyngedouw and Boelens, Forthcoming).

The notion of (contested) imaginaries - central to hydrosocial territories - describes how divergent interest groups and actor alliances interpret current territorial constellations and how they need to be reconfigured in the future. Future visions entail clear aspirations and ideas of how hydro-technical and social plans must become realized through corresponding values, symbols, norms, institutions and social relationships. Imaginaries, thus, can be understood as the socioenvironmental world views and wished-for patterning of the material and ecological territorial worlds -"patterned convocations of the social whole" (Steger \& Paul, 2013:23). Imaginaries are underpinned by discursively framed problem definitions; about what constitutes valid knowledge and what are 'good' water management approaches. Beyond merely imaginary entities, only existing in the minds of people, they are powerful forces that drive material, techno-political actions (Hoogesteger et al., 2016). Hirsch (2016:65) details in an insightful recent paper about the Mekong region, how geographical imaginations and representations ("Mekong ontologies") have physical real-life effects, shaping water management outcomes. Yet, compared to ontologies and theoretical notions on existing orders of objects and the ties between them, hydro-territorial imaginaries are also intrinsically political and ideological interpretations and projections of how water, geography and people should be aligned and governed. To achieve realization of territorial imaginaries, interest groups take shape to combine economic, political and discursive resources. Especially the fact that mega-hydraulic infrastructure projects are capital-intensive and require modernist high-tech, forces the formation of interest groups and actor coalitions (see, for example, Molle, Mollinga, \& Wester, 2009; Swyngedouw, 1997).

Concerning the role of hydraulic infrastructure in shaping territories or forms of statecraft, numerous scholars have made important new contributions since Wittfogel's classic thesis on hydraulic despotism. Anand (2011:551), for instance, explains how water "plays a critical role mediating the relationship between the government and the governed". In this paper, however, we consider hydraulic infrastructure in a broader sense: as mediating not only the relationship between the rulers and the ruled but as powerful socio-technical and cultural-political connector among different water users, territorial imaginaries, knowledge systems, and socioecological environments (see Boelens, 2015; Duarte-Abadía et al., 2015; Linton \& Budds, 2014; Seemann, 2016; Vos \& Hinojosa, 2016). Through the construction of dams, canals and hydropower plants, the Lima region's physical-ecological, socio-cultural and political-institutional relations become reconfigured. Reconfigurations resulting from hydro-territorial projects are disputed in multiple covert or overt ways and constantly negotiated in everyday practices, political-legal arenas and physical designs. Thereby, affected water users may change the ways technologies are used in unforeseen ways.

Nevertheless, the scope for negotiating social order and hydroterritorial schemes is, to a certain degree, restricted by the hydraulic technologies put in place. Though we distance ourselves from technological determinism, technology design and construction embody and later facilitate certain types of social norms, behaviours, relationships and social requirements for use, while omitting and excluding others (Mollinga, 2003; Pfaffenberger, 1988; Winner, 1986). As Jensen and Morita (2016:6) state, "infrastructures hold the potential capacity to do such diverse things as making new forms of sociality, remaking landscapes, defining novel forms of politics, reorienting agency, and reconfiguring subjects and objects, possibly all at once". Hydraulic infrastructures and the inscribed social norms are a powerful force, bringing about new configurations of spatially- and temporallybound practices, networks and ideas. The construction of infrastructure and water management arrangements is thus always a reflection of political interests and discourses (Kelly-Richards \& Banister, 2016).

The conceptual notion of hydrosocial territories is, in this paper, applied to understand the reconfigurations of rural-urban hydrosocial territories triggered by urbanization processes and politics. In that regard, the research is embedded in literature that unpacks how urban development is intrinsically based on the appropriation and transformation (or: 'urbanization') of nature. Cities are seen as encapsulated in networks of environmental, political, economic and social relations that exceed their conventional boarders and geographies (Anand, 2011; Cronon, 1991; Gandy, 2004). Such appropriations and transformations of nature through urbanization processes often take place under the banner of modernity and progress. As we elaborated before, infrastructures thus operate at levels of imaginaries and desire, representing "the possibility of being modern, of having a future" (Larkin, 2013: 333, cf.; Banister \& Widdifield, 2014). This results in tensed, conflictual relationships between geographical imaginations of modernization and urbanization, and the actual social, economic and ecological costs generated by modernity imaginations (Illich, 1985; Kaika, 2006). Theorizing urbanization as a complex, multi-scalar, multi-dimensional process has been done by several political ecology scholars (see e.g. Heynen \& Swyngedouw, 2003; Swyngedouw, 2015; Kaika, 2006). Yet, many studies do not take analyses beyond city boundaries but focus on nature or water within the city (see e.g. Anand, 2011; Ranganathan, 2014). Our study and approach sets out to move beyond the city to focus on a political ecology of urbanization (complementary to a political ecology of the city) and, thereby, show how urbanization differentiates as well as intertwines city and countryside (cf. Angelo \& Wachsmuth, 2015).

\section{A historic hydraulic mission: imaginations of Lima as the illuminated garden city}

Hydraulic infrastructure as present in the Lima region today is outcome and materialization of specific ideas, imaginaries and desires that date back to the early 20th century. Analysing how territorial claims of hydropower companies and Lima's drinking water company have evolved through time allows depicting the way in which nature was transformed under banners of modernity and progress (cf.Banister \& Widdifield, 2014; Gandy, 2004). It also illustrates how territorial reconfigurations originate in powerful imaginaries about people and the environment in the Lima area, with effects that endure until today. At the same time, the fact that the original transfer idea did not become realized as it was shows how imaginaries do not automatically turn into territorial projects, but need additional financial and political resources mobilized to their advantage.

The first one to call for transferring water from the Mantaro valley to the Rímac watershed was electric engineer Santiago Antúnez de Mayolo, to today celebrated as the pioneer of hydropower development in Peru. Already in 1929, he explained that "Lima, the 'Pearl of the Pacific', needs to bedeck herself at night with potent bundles of light shining over her and neighbouring populations" (Antúnez de Mayolo, 1929:1). Some years later, he added that not only light is needed but also food supply: "what concerns Greater Lima, [...] her fundamental problem, worsened by speeding 
urban growth, will always be food supply" (Antúnez de Mayolo, 1953). Accordingly, Antúnez de Mayolo proposed an ambitious engineering project to dam Junín Lake, Peru's second-biggest lake and now a national nature reserve, and divert its waters through a $40 \mathrm{~km}$ trans-Andean tunnel to Lima's coast. What is remarkable is that this massive hydraulic engineering project did not primarily aim to supply drinking water to Lima, but to enable the development of large-scale irrigation on the coastal desert land around Lima. Water use for hydropower was an additional side effect. Antúnez de Mayolo argued that land lying bare was a waste of national resources, needing to be developed to grow cotton and sugar for export and to ensure food security for Lima:

"The Peruvians of tomorrow [...] will lift up the monument of granite which will eternalize the heroic deed of the epigones who achieve such a gigantic work, to fecundate the desert wasteland [...], provide light and power and, in general, to increase the richness, comfort and beauty of Greater Lima, the Garden City of the Southern Hemisphere" (Antúnez de Mayolo, 1953: book cover).

This reveals, first, a glorification of engineering work as utopianinspired hydraulic heroism (cf. Boelens and Post Uiterweer, 2013); second, the vision of a desert to be fertilized by water, no matter from where (cf. Maas \& Anderson, 1978); and third, envisioning Lima as the modern place-to-be, with abundant food, energy and water resources. At the same time, this vision contains an imaginary of a hydro-territorial disequilibrium of fertile lands and population on the Pacific coast and water resources in the Amazon basin - a disequilibrium to be overcome by modern technology and the conquest over nature (cf. Swyngedouw and Boelens, Forthcoming). For example, the national El Comercio newspaper stated that "[the water transfer] attempts to equitably balance the water abundance and scarcity originating from the "divortium aquarium' of the Andes" (El Comercio, 1950). Such discourse about water transfers from the (Amazon-flowing) Mantaro watershed to balance the mismatch between people, arable land and water resources persists to this day, as most reports about Lima's water situation start by observing that one-third of Peru's total population lives in the capital city, while only $2.2 \%$ of the nation's water resources are found there (see for example Aquafondo, 2013; Riveros et al., 2014).

While these numbers might roughly represent empirical water flows, such a portrayal hides possible downstream effects under imaginaries of abundance and scarcity. A possible distribution dilemma within the two geographical areas, in which more water for one user means less for another, is brushed away, further justifying the transfer of water as an endeavour to serve up justice in an "unjust natural system" (Headline in El Comercio, 1959a: 3). Embedded in such strong discourse and imaginaries, it becomes difficult to challenge or question the transfers. This is further reinforced by deep beliefs in the superiority and fundamentality of engineering science for modernity and progress. Characteristic quotes speak for themselves: "The application of engineering science as an activity is intensively bound to industrial progress and economic wealth" (El Comercio, 1950) and "transforming the dramatic topography of the Andes - hostile barrier to Peruvian man and his life needs - is a singular ambition and idealistic goal, driving force of progress for a beautiful metropolis" (Gino Bianchini, former director of Electric Companies at the inauguration of the HPP Huampaní, 1960).

However, Antúnez de Mayolo's idea did not materialize after all. His plan was seen as too ambitious as it envisaged a $40 \mathrm{~km}$ long tunnel through the Andes and lacked financing. Furthermore, according to a SEDAPAL representative, social protests around the
Junín Lake were a reason not to realize the project (Interview Department of Research \& Development, SEDAPAL, August 2015). Later, the idea to transfer water was picked up and adjusted by Swiss engineer Pablo Boner who was working for the Associated Electric Companies of Lima. De Mayolo and Boner knew each other, even though they never directly collaborated (Interview A. Boner April 2016). Boner was well aware of the earlier transfer design. In an interview (El Comercio, 1950) he was sceptical, arguing that more hydro-geological studies would be necessary and that, furthermore, Antúnez de Mayolo's idea for financing tunnel construction would be difficult to realize. Boner's emphasis was clearly on transferring water to be used first and foremost by hydropower, and not on benefits for the agricultural sectors, as was Antúnez de Mayolo's idea. The fact that Boner, since the 1930s, had led the construction of four hydroelectric power plants in the Santa Eulalia and Rímac watersheds is likely to have influenced his opinion (Boner, 1949).

Accordingly, Boner designed a different water transfer that would tap the closer Lagoon of Marcapomacocha (upper Mantaro watershed) instead of Lake Junín, and transfer its water through open canals and a $10 \mathrm{~km}$ tunnel to the upper Santa Eulalia subwatershed (see Fig. 1). The project, which came to be known as Marca I, was inaugurated in 1965 and had the explicit objective to provide water to hydropower plants as a supplement to the irregular river and rainfall regime of the Santa Eulalia. Drinking water supply for Lima and possible irrigation water figured as minor matter only (Empresas Eléctricas Asociadlas, 1959). Increased and steady electricity production was regarded as more important concern for an expanding city.

What was essential for the realization of this project, which set the cornerstone for the two following water transfer projects, was that Boner managed to convince foreign investors to support the project with financial resources. Besides funds from the International Bank for Reconstruction and Development (IBRD), Swiss support played a key role (Empresas Eléctricas Asociadas, 1960). Already in earlier difficulties of the Electric Companies in the 1930s, Boner and his colleagues were able to mobilize Swiss capital to finance the expansion of hydropower in Lima (Cámara de Comercio Suiza en el Perú, 1991). In fact, much of the board of directors and leading engineers of the Electric Companies as well as the associated company Hidrandina was composed of Swiss and Italian expats with good relations with Swiss banks, companies and investors. These relations and conjoint business ventures were part of a broader Swiss involvement and economic aspirations in Peru, which helped to find support for the water transfer project (ibid; cf. Sanders, 2015). As one of Switzerland's main daily newspapers declared with pride: "the exemplary electricity supply of the two million city Lima is fundamentally the work of Swiss mind", "a piece of Swiss homeland exerted with grandeur in the distance" (Neue Züricher Zeitung, 1964:6). In comparison to such broader support for Pablo Boner, Antúnez de Mayolo's idea and imaginary clearly lacked necessary financial and political resources.

Marca I was a milestone for Lima's and also Peru's water management: it showed that engineering can win over nature and put nature at the service of modern cities and progress. Hermann Buse's landmark book Huinco 200,000 KW (1965) describes this process of transforming river flows and landscapes. His account is marked, on the one hand, by a vision of nature as hostile enemy; and on the other hand, by a personification of nature that also expresses respect for nature's forces. For example, he describes the construction of the trans-Andean tunnel as a "battle in the tunnel" (p.55), "a tough fight against the masses of rocks" (p.55), an "attack against the mountain range" (p.93) and at the end, the "final victory" (p.105) of humans over nature, with the result that "humans modify geography" (p.85). At the same time, subterranean streams 
exposed during perforation works are portrayed as "invisible veins of the mountain" (p. 55), which shows how the landscape is personified and compared to a human body. However, before the conquest of nature by engineering science, workers and machinery, the river is merely an uncontrollable savage. It is only once transformed into a hard worker that the waters are bestowed with awe for force and contribution to the advent of modernity: "the Rímac and the Santa Eulalia ... the most hard-working rivers in the world" (Buse, 1965:3). Or, as the former director of the Electric Companies put it: "the works that give fructuous discipline to the water flows of the Santa Eulalia and Rímac Rivers arise like awe-inspiring holy altars for the progress of the Nation" (Bianchini, 1960; emphasis added).

As the last already demonstrates, Buse's book is not an isolated documentation or vision. Besides his numerous publications and homages in the main national newspaper El Comercio (1959a,b, $1960,1968)$ that have informed public opinion, many similar accounts exist. For example, a Spanish journalist cited by Antúnez de Mayolo (1953), exclaims: "What an immense triumph for the persistence of Peruvian engineers, viewing one day [...] the waterabundant Mantaro dominated by science and subordinated by genius!", depicting big admiration for engineers' ability to dominate and civilize nature for progress and development. At the same time, Pablo Boner himself expressed modesty about his accomplishments as opposed to the rivers' contribution. According to his nephew and former colleague, he accepted the Peruvian Cross of Merit only reluctantly, saying: "it was not me who made the mountains" (Interview A. Boner April 2016). These accounts show the dualism between respect for nature's forces and regarding nature as an enemy; something peculiar and often overlooked in literature on the hydraulic mission and the glorification of engineering.

As has been indicated, the first water transfer did not primarily focus on drinking water supply for urban Lima. The missing consideration and importance of drinking water supply for Lima City's population given the then still sufficient locally available water resources and the much smaller population, explains why the drinking water company SEDAPAL was not involved, even though it is nowadays commonly assumed that the Water Company initiated all Marca projects. Accordingly, to this day, SEDAPAL does not actually own the central node of the hydraulic infrastructure system supplying Lima City with water: the trans-Andean tunnel. Nevertheless, with raising concerns about urban water supply. SEDAPAL became involved in two water transfers: for Marca III (1999) as co-financier and for Marca IV (2012) as main implementer in a public-private partnership. Thus, supposed needs and objectives changed; so did mechanisms that sustain and further drive trans-Andean water transfers. This will be analysed in the following section, building the bridge to an analysis of the current situation by means of the study of the most recently implemented water transfer.

\section{Emerging water control in the Mantaro andRímac watersheds}

Once installed, the infrastructure systems in Lima have been accompanied and justified by changing objectives, actor alliances and mechanisms. On the one hand, this shows how imaginaries, discourses and mechanisms surrounding and sustaining particular infrastructure are changing throughout time and are not as fixed as their materialities seem to suggest. On the other hand, it also demonstrates how the same infrastructure development continues to be implemented despite the governance context, only on different grounds. Disclosing how additional legal and discursive mechanisms have produced and supported infrastructure development until today will thus complement the historic analysis of

\section{imaginaries.}

With the increasing involvement of Lima's Drinking Water Company SEDAPAL, an institutional and discursive system evolved around the water transfers that is underpinning and moulding ongoing territorial reconfigurations. Our analysis of changing actors, justifications and mechanisms shaping the transfer of water to the Limenian coast focuses on three main aspects. First, the way in which transfers reconfigure ownership arrangements over water and its regulation. Second, how these arrangements become institutionalized, thereby invisibilizing transfers as well as deterritorializing water resources. And third, how the acknowledged inherently political and contested nature of the water transfers is being neutralized through discourses of water scarcity and cultural backwardness in areas from where water is obtained. The identified components exist as a powerful combination that reconfigures rural-urban hydrosocial territories in the Lima region.

Institutionalizing and invisibilizing extractive transfers - claiming territorial control

With time, water transfers from the Mantaro basin to Lima have become embedded in and sustained by a legal-political system that facilitates them and makes contestations increasingly difficult. Most importantly, the water transfers have led to a changed understanding of water ownership. Whereas Peruvian law establishes that water is property of the Peruvian nation and that there may not be any private property over water (Water Resources Law, 2009), the water flowing in canals of the two companies is seen to belong to the companies - at least for the part of the watercourse where water is conducted in pipelines and canals (most of the Santa Eulalia and Rímac Rivers). "We own and administer the water as long as it flows in one of our canals", explains a SEDAPAL representative (Interview August 2015). A hydropower engineer confirms: "Together with SEDAPAL we are co-proprietors" (Interview March 2016). The Rímac Water Users Association president explains how this can lead to arguments between downstream water users and companies: "EDEGEL and SEDAPAL are regulating discharge now. They make these mega-projects; everything is private $[. .$.$] . We are not using the water from this infrastructure,$ because we use the Rímac River's natural flow [...]. But sometimes, they complain and say that we are stealing their water; but that is not true. [...] I am not interested in their water but I do respect it" (Interview September 2015). Thus, waters that are regulated through hydraulics have become property of those actors that have designed and constructed the hydraulics. Such forms of 'humanizing water' through hydraulic investments often constitute the fundamental part for establishing categories of ownership and property in the region. Accordingly, drawing boundaries between what is natural and what is social is itself part of struggles over water.

Corresponding property manifestations can be found all along the system: locks on water gates, barbed wire around parts of the Marcapomacocha Lagoon, and legal-administrative arrangements, securing the boundaries of 'appropriate uses' and 'rightful appropriation'. Where river and transfer water is currently still flowing in the riverbed (in the lower Rímac watershed, below the Huampaní hydropower plant), a project is planned to also conduct water in tunnels (Céspedes Alarcón, 2014). Tellingly, the project is strongly opposed by the Rímac Water User Association, which fears less water availability and restricted control over water flows for other water users (Interview September 2015).

The legal-administrative arrangements further alienate and deterritorialize water resources from their geographic origins and thereby also from their possible political implications and effects on other water users (cf. Banister \& Widdifield, 2014). For example, 
licenses to water and electricity companies do not specify water sources but simply authorize intake of "surface waters coming from the Rímac River" (MINAGRI, 1995) even though the water quantity (here, $20 \mathrm{~m}^{3}$ per second) clearly indicates that part of it comes from the Mantaro. The water law and issued licences thereby appropriate water from the Mantaro watershed, subtly redefining it as originating from the Rímac River and obscuring the fact that large volumes of water flowing through the Santa Eulalia watershed in fact come from the Mantaro watershed. Attention and questions about water transfers are averted.

The powerful downstream perspective disregarding actual water sources is also manifested in authority structures and accompanying responsibilities established to grant water-use licenses: the Local Water Authority of the Mantaro watershed is not formally responsible for issuing the licenses, but the Local Chillón Rímac Lurín Water Authority. The law states that "the administrative procedures in water matters are initiated by [...] application to the Local Water Authority in whose jurisdiction the water will be used. If the natural source of the water and the possible intake point are situated in the jurisdiction of another Local Water Authority, their opinion will be inquired" (MINAGRI \& ANA, 2010; emphasis added). Thus, the Mantaro Water Authority's opinion about availability of water resources for a transfer is taken into account but the factual authority to issue or reject licenses lies with Lima's Water Authorities. In the process of assessing water availability, upstream communities without formally registered water rights (which many reject due to fears of payment obligations) may potentially have disadvantages. Although Peruvian law recognizes and respects peasant and native communities' water use rights it is unclear how such recognition is taken into account in actual bureaucratic practices. Customary, socioterritory-based water rights notions, as held by many Andean user communities, are commonly dismissed in everyday practice (Boelens \& Seemann, 2014; Rodríguez-De-Francisco \& Boelens, 2016; Roa-García, 2014; Vos, Boelens, \& Bustamante, 2006).

Water transfers are also facilitated by the Water Law's prioritization of water uses, which ranks drinking water first in accordance with the international discourse on the human right to drinking water and the Millennium and Sustainable Development Goals. In consequence, SEDAPAL's water claims will always have legal priority even though part of the drinking water is used for tourism and industrial activities or to water parks. Conversely, Andean communities' customary water uses are classified as lower-ranking irrigation use, while in practice they often serve multiple purposes in these communities, including drinking water supply.

Finally, water is formally national property and water for Lima is national priority, so mega-projects in the Mantaro watershed are legalized by supreme decrees signed by the President himself. This gives substantial political and legal weight to projects, sometimes leading to a sense of helplessness and subordination among people affected by projects. One community member displaced by the Huascacocha project explains: "There was a supreme decree issued by the government, so what can we do against the project? We cannot do anything" (Interview August 2015). Thus, hydraulic projects are by no means illegal undertakings but are part of a broader legal-political system. In this hydro-territorialization process, hydraulic projects shape the need for and contents of legislation, which enables and institutionalizes extractive water practices and infrastructure development.

Neutralizing the political through discourses on water scarcity and cultural backwardness

Since the 1990s SEDAPAL representatives acknowledge the political nature of the water transfers by admitting that much coordination and explication work is needed to convince rural communities to accept the projects. However, up to this day, communities' doubts or opposition to transfer projects are commonly reduced to matters of ignorance. For example, in one interview, a representative of SEDAPAL stated that "Megaprojects are all about coordination with peasant communities. They must be sensitized" (Interview September 2015). A similar vision has been present since the implementation of the first water transfer explicitly aimed at providing drinking water. As the following from the SEDAPAL book Land of Lagoons demonstrates (published on the occasion of inaugurating Marca III), rural communities are portrayed as in need of integration and a dose of reality, which the promising Marca III project is imagined to bring. Any opposition is seen as indifference, ignorance or stubbornness, easily resolved by education and sensitisation: capacitating the incapable.

"Living in a natural paradise, they [communities in the project region] find themselves a bit distant from the reality which our country lives, and even more so from the destitutions and necessities of other Peruvian regions. Accordingly, their initial attitude was one of indifference towards the great project that will benefit the regions of Lima and Callao with new water sources. [...] We thus began a long road of negotiations with communities in Yantac, who turned out to be distrustful and worried about the possible negative effects of the project in the zone. [...] Nevertheless, SEDAPAL [...] planned a series of actions to benefit the community [...] such as this book, which documents a historic compilation of the Andean highland communities' archaeology, culture, folklore, flora and fauna, and which furthermore has the value of striving to integrate the most remote communities and those least informed about the country's reality. [...]

Explanations about the project's kind-heartedness and the seriousness of SEDAPAL's commitment conquered local leaders' resistance, and they made the historic decision to facilitate this project, which offers the solution to one of the biggest problems for Peru's capital city" (SEDAPAL, 1998:17-18).

Thus, projects that cut through local territories to supply water to the downstream city build upon a socioterritorial imaginary in which the countryside is of abundant resources and backwardness, and the city a place of cultural richness (civilized society and progress) paired with water scarcity (cf. Wachsmuth, 2012). The city is equated with scarcity and progress; the country with abundance and backwardness. While being clearly differentiated, city and county are, at the same time, also connected through actual water flows and infrastructure construction. "Socionatural processes spanning city and countryside differentiate the two at the same time as they connect them" (Angelo \& Wachsmuth, 2015: 25).

Another aspect, which is an essential driving force for the reconfiguration of hydrosocial territories in the Lima region and which connects to the particular country-city distinction, is the water scarcity discourse. The narrative of Lima being the second biggest desert city in the world after Cairo is announced at the beginning of almost every presentation or pamphlet by SEDAPAL and other international and national institutions working in the area (see for example Aquafondo, 2016; Pasco-Font, 2015). What often remains unmentioned in such a narrative is the inequality in water access within the city: while around one million inhabitants in Lima still lack access to public drinking water and sanitation systems, in the most exclusive neighbourhoods pools are filled and parks extensively irrigated (Ioris, 2012). Yet, a general water scarcity narrative, which emphasises water deficits because of growing urban water demands and Lima's location in a desert, obliterates 
these inequalities within the city and instead justifies investments in massive water supply projects (cf. Lynch, 2013). As a result, the water transfers are promoted as charitable 'water for all' projects even though the water often does not reach those most in need. With the category of 'the thirsty city Lima', the voices of marginalized populations disappear, and city and countryside categories become part of a particular politics of scale.

Together with a discourse about water abundance in the Mantaro watershed, the water scarcity discourse justifies the continuous expansion of Lima's water supply system. The complexity of the water problem is reduced to a rather simple - or at least unambiguous - distribution problem between two large geographical areas: the desert coast and the Amazonian basins. Possible water distribution dilemmas within these geographical areas remain unmentioned. This is to say that not for everybody living on the Amazonian side of the Andes water abounds. For example, in the city of Cerro de Pasco, which is located close to the last water transfer Huascacocha (Marca IV), water access and supply is a massive problem (El Comercio, 2014).

The specific framing of the problem (distribution) and the solution (re-distribution) on rather large and simplifying scales, also excludes other approaches to tackle the so-called water crisis in Lima. For example, the multi-stakeholder LiWa project (2008-2014), of which SEDAPAL also formed part, identified different steps towards a more sustainable water future in Lima, of which none explicitly included the acquisition of further Mantaro resources. Instead, the action plan points, amongst others, to the high water losses within the urban water distribution system that can be addressed through maintenance works and fixing of leakages; the big and still unexplored opportunities for reusing treated waste water; demand management through adjusting the water tariff structure; and massive awareness raising campaigns amongst consumers (León, 2013). Yet, water transfers continue to be the preferred option. The fact that the President in charge normally inaugurates the transfers and other visible and marketable water projects makes massive infrastructure more easily functionalized for political purposes. National politicians are more likely to gain votes with inaugurating a water transfer than advocating maintenance works of underground pipes that are less visible in everyday life and people's consciousness. As former Peruvian president Ollanta Humala explained during the inauguration of the Marca IV transfer project: "With this type of [infrastructure] works we are constructing trust" (RPP Noticias, 2012).

After having analysed legal and discursive mechanisms that have produced and supported infrastructure development until today, we now focus on the material, social and symbolic effects of the associated territorial reconfigurations. We do so through a closer study of the latest water transfer project Marca IV.

\section{Diverging implications for different water users - the case of the Marca IV project}

What specific effects do water transfers actually produce locally? Are rural communities left without water? Who is benefiting, who is disadvantaged? The following section analyses these questions for the most recently implemented transfer project. The "Huascacocha - Rímac Derivation" project, also called Marca IV, was inaugurated in 2012 by then president Ollanta Humala, as the first water transfer implemented in the Mantaro watershed by a public-private partnership. The twenty-year concession involves planning, operation and maintenance responsibilities as well as negotiations with local communities. The Peruvian Water Company (EPASA - Empresa Peruana de Aguas S.A.) is, other than the name suggests, a consortium of two subsidiaries of Brazilian construction giant OAS. The project involves a $15 \mathrm{~m}$-high dam in the natural
Huascacocha Lagoon, from where a canal conveys water to the Marca III system and then to the Santa Eulalia watershed (see Fig. 1). A total of four rural communities are considered to be affected.

Communities claim negative effects of the project and explain that negotiations about compensation have been unfair, with unequal negotiation skills between experienced EPASA lawyers versus inexperienced communities; that more pasture land than originally agreed upon has been flooded without compensation, and that canals endanger humans and animals while crosscutting territories and impeding livestock movement and grazing. One member of a local community close to the Huascacocha Project, for example: "the canal and the project have divided our territory. The company has divided as they pleased. Today a lot of cars pass through here and at the same time our animals cannot pass as they used to" (Interview August 2015). In one community, water access problems exist: "now there is no more water for us, especially in summer [...] we experience water shortage, leading to deaths of alpacas. So we are in conflict with the company. [...] The agreement says that they should only collect the water harvest from the winter rains and divert this, but in reality they divert everything and leave nothing for us" (Interview August 2015).

Besides these concerns, communities and the regional government in the project area regard it as unjust that millions of dollars are invested in the project, while at the same time local communities are left without safe local drinking water systems. "In the region of Pasco we don't have water; they take most of the water to Lima. They deceived us ( ...). There is no benefit for us from the project, no support. How much might they be earning with it? While we live like this ...." (Interview with community member, August 2015). Especially in the nearby city of Cerro de Pasco, drinking water is a major issue as it is only provided a couple of hours a day. Much water is, therefore, supplied by private water tanks which makes water in Cerro de Pasco on average the most expensive in all of Peru (El Comercio, 2014). As a result, the Regional Government and an NGO from Pasco have also become involved in the debate around Huascacocha and other future water-transfer projects, arguing that transferring this water deprives Cerro de Pasco of any future possibility to use the water for their own drinking water supply: "SEDAPAL didn't bring any benefit for us. For example, they should have provided water to the villages because many have neither drinking water nor a sewage system" (Interview Regional Government Pasco, Department of Natural Resources, August 2015). Likewise, an NGO representative: "We have a longterm vision and are afraid that one day the coast may have water while we are left with nothing; because the water of this region is not inexhaustible" (Interview Centro Labor Pasco, August 2015). This shows how concerns connected to the Huascacocha transfer project are partly about possible local water shortages in the future, but also about the perceived unjust gap between investments for Lima and for community needs. Local drinking water problems stand in stark contrast to skyrocketing investments for Lima, and leave communities and regional institutions with a sense of being secondary citizen; subordinated to capitalist business ventures extracting water and profits from the area.

Yet, overt contestations about these issues are rare. Complaints are expressed verbally and in written form, but in general an imaginary about non-contesting and accepting communities prevails. Some blame this on the area's long mining history that is said to have weakened community ties (cf. Sosa \& Zwarteveen, 2011; Stoltenborg \& Boelens, 2016); others see communities as helpless versus projects of national priority. Others say that hopes for benefits and local employment generation prevail, despite scepticism about whether benefits will become a reality: "These companies don't recognize communities; our complaints and our situation 
mean nothing to them" (Interview community member, August 2015). Even though one can certainly not talk about an open water conflict or struggle, the above outlined project implications and perspectives have questioned the imaginary of the "Land of the Lagoons" as a land of untapped resources that simply requires investment, hydraulic infrastructure and sensitization of rural communities.

\section{Conclusions}

The paper set out to scrutinize the ways in which urbanization processes in the region of Lima drive a profound reshaping of ruralurban hydrosocial territories, differently affecting water user groups' access to and control over water resources. The analysis of the history of water transfers in Lima shows how objectives for water transfers have changed over time and how specific discourses have substantially supported megaprojects: about engineering as a silver bullet to balance a 'natural disequilibrium', about the need to put every drop of water to productive use, and about the aspiration to turn a desert city into an illuminated garden. Such analysis has enabled us to decipher and unmask hydraulic systems as being far from a logical consequence of Lima's location in a desert. Instead, spatial imaginaries about city and countryside, water scarcity and abundance, and about progress and backwardness are at the core of the water transfers in the Lima region. However, while certainly very powerful, it has also been demonstrated that imaginaries do not automatically turn into geographical forces as such, but require further financial and political support to become materialized. Thus, only those who can mobilize these elements in conjunction will be able to reshape hydrosocial territory according to their interests and ideas. In effect, rural water users are confronted with the consequences of the territorial reconfigurations resulting from Lima's upscaling search for water supplies beyond its geographically corresponding watersheds. While the infrastructure system and legal-institutional government techniques mean control and access for hydropower and drinking water companies; they imply dependence and/or exclusion from the benefits for rural communities. Beyond questions of outright water grabbing, local communities' loss of decision-making power and control over their territorial waters as well as the distribution of water-related benefits are central.

Besides its empirical contribution, the paper has fruitfully engaged political geography and water governance scholarship, combining conceptual notions of territory, imaginaries and hydraulic infrastructure. Through the paper's emphasis on historically-rooted imaginaries, it has been shown how cities are not automatically implicated in multi-scalar and multi-dimensional networks, but how the city's very own geographies are actively constructed through discourses and imaginaries. Specific scarcity and abundance discourses as well as scale categories and what is to belong to 'the city' are defined by actor alliances with discursive, political and financial power who can then cement these imaginaries in hydraulic infrastructure. In these processes of territory making, openly political and disruptive water supply projects are powerfully institutionalized and justified, also naturalizing complexities and politics of water crisis. Yet, as an addition to scholarship that depicts infrastructure as tool to subjugate populations and extend state control, the conceptual notion of hydrosocial territory employed in this paper emphasizes the territorial diversity existing within one and the same geo-political location, which in turn leads to considering territorial reconfiguration as an ongoing process of negotiation and struggle.

\section{Declaration of conflicting interests}

The authors hereby declare that there is no conflict of interests.

\section{References}

Agnew, J. (1994). The territorial trap: The geographical assumptions of international relations theory. Review of International Political Economy, 1(1), 53-80.

Anand, N. (2011). Pressure: The PoliTechnics of Water Supply in Mumbai. Cultual Anthropology, 26(4), 542-564.

Angelo, H., \& Wachsmuth, D. (2015). Urbanizing urban political ecology: A critique of methodological cityism. International Journal of Urban and Regional Research, 39(1), 16-27.

Antúnez de Mayolo, S. (1929). Génesis de los servicios eléctricos de Lima. Lima: National Library of Peru.

Antúnez de Mayolo, S. (1953). La gran Lima y la desviación del río Mantaro al Rímac. Lima: National Library of Peru.

Aquafondo. (2013). In Rodrígues, et al. (Eds.), Planificación estratégica para la conservación en el esquema del Fondo de Agua para Lima y Callao. Lima: The Nature Conservancy.

Aquafondo. (2016). Lima, megaciudad en el desierto [Online]. Available: http:// aquafondo.org.pe/wp-content/uploads/2015/11/1._Lima_Megaciudad_en_el_ Desierto.pdf [accessed 20.09.16].

Autoridad Nacional del Agua. (2010). Estudio hidrológico y ubicación de la red de estaciones hidrométricas en la cuenca del río Rímac. Lima: Ministerio de Agricultura.

Bakker, K. (2010). Privatizing water. Governance failure and the world's urban water crisis. Ithaca, NY: Cornell University Press.

Baletti, B. (2012). Ordenamento territorial: Neo-developmentalism and the struggle for territory in the lower Brazilian Amazon. Journal of Peasant Studies, 39 $573-598$.

Banister, J. M., \& Widdifield, S. G. (2014). The debut of 'modern' water in early 20th century Mexico city: The Xochimilco potable waterworks. Journal of Historical Geography, 46, 36-62.

Barnes, J., \& Alatout, S. (2012). Water worlds: Introduction. Social Studies of Science, 42(4), 483-488.

Baviskar, A. (2007). Waterscapes. The cultural politics of a natural resource. Delhi: Permanent Black.

Bianchini, G. (1960). Inauguración central Hidroeléctrica. Lima: Private Archive A. Boner.

Boelens, R. (2014). Cultural politics and the Hydrosocial cycle: Water, power and identity in the Andean highlands. Geoforum, 57, 234-247.

Boelens, R. (2015). Water, power and identity. The cultural politics of water in the Andes. London: Earthscan, Routledge.

Boelens, R., Hoogesteger, J., Swyngedouw, E., Vos, J., \& Wester, P. (2016). Hydrosocial territories: A political ecology perspective. Water International, 41(1), 1-14.

Boelens, R., \& Seemann, M. (2014). Forced engagements: Water security and local rights formalization in Yanque, colca valley, Peru. Human Organization, 73(1), $1-12$.

Boelens, R., \& Post Uiterweer, N. C. (2013). Hydraulic heroes: The ironies of utopian hydraulism and its politics of autonomy in the Guadalhorce Valley, Spain. Journal of Historical Geography, 41, 44-58. http://dx.doi.org/10.1016/ j.jhg.2012.12.005.

Boner, P. (1949). Los servicios eléctricos. Lima: National Library of Peru.

Brenner, N. (1998). Between fixity and motion: Accumulation, territorial organization and the historical geography of spatial scales. Environment and Planning $D, 16,459-481$.

Brighenti, A. M. (2010). On Territorology - Towards a general science of territory. Theory, Culture \& Society, 27(1), 52-72.

Budds, J., \& Hinojosa-Valencia, L. (2012). Restructuring and rescaling water governance in mining contexts: The co-production of waterscapes in Peru. Water Alternatives, 5, 119-137.

Buse, H. (1965). Huinco 240,000 KW. Lima, Peru.

Cámara de Comercio Suiza en el Perú. (1991). Presencia Suiza en el Perú (Lima).

Celio, M., Scott, C. A., \& Giordano, M. (2010). Urban-agricultural water appropriation: The Hyderabad, India case. Geographical Journal, 176, 39-57.

Céspedes Alarcón, J. (2014). Conducción fuera de cauce de aguas reguladas del río Rímac entre Moyopampa y La Atarjea. Lima: SEDAPAL.

El Comercio. (1950). Reportaje al Ingeniero Pablo Boner sobre el Proyecto de Desviación de las Aguas del Río Mantaro al Rímac. Lima.

El Comercio. (1959a). Huinco: Primeras victorias - Batalla por el agua, 10 June 1959, Lima.

El Comercio. (1959b). Huinco: Primeras victorias - altura 5.000, 12 June 1959, Lima. El Comercio. (1960). Huinco, 28 June 1960, Lima.

El Comercio. (1968). Justo Homenaje, 24 May 1968, Lima.

El Comercio. (2014). El agua cuesta entre 30 y 50 veces más en Pasco y Pucallpa [Online]. Available: http://elcomercio.pe/economia/peru/agua-cuesta-entre-30y-50-veces-mas-pasco-y-pucallpa-noticia-1765741 [accessed 10.10.15].

Damonte-Valencia, G. (2015). Redefiniendo territorios hidrosociales: Control hídrico en el valle de Ica, Perú (1993-2013). Cuadernos de Desarrollo Rural, 12(76), 109-133.

Cronon, W. (1991). Nature's Metropolis. New York: A.A. Norton.

Doucette, J., \& Lee, S.-O. (2015). Experimental territoriality: Assembling the Kaesong 
industrial complex in North Korea. Political Geography, 47, 53-63.

Duarte-Abadía, B., Boelens, R., \& Roa-Avendaño, T. (2015). Hydropower, encroachment and the re-patterning of hydrosocial territory: The case of Hidrosogamoso in columbia. Human Organization, 74, 243-254.

Elden, S. (2010). Land, terrain, territory. Progress in Human Geography, 34(6), 799-817.

Empresas Eléctricas Asociadas. (1959). Obra Marcapomacocha. Lima: National Library Peru.

Empresas Eléctricas Asociadas. (1960). Memoria anual, archive museum of electricity Lima.

Escobar, A. (2008). Territories of difference: Place, movements, life, redes. Durham NC: Duke University Press.

Gandy, M. (2004). Rethinking urban metabolism: Water, space and the modern city. City, 8(3), 363-379.

Grundy-Warr, C., Sithirith, M., \& Li, Y. M. (2015). Guest Editorial - volumes, fluidity and flows: Rethinking the 'nature' of political geography. Political Geography, 45, 93-95.

Haraway, D. (1991). Simians, cyborgs, and women: The reinvention of nature. New York: Routledge.

Hassner, P. (1997). Obstinate and obsolete: non-territorial transnational forces versus the European territorial state. In O. Tunander, et al. (Eds.), Geopolitics in the Post-Wall Europe: Security, Territory and Identity. London: Sage.

Heynen, N., \& Swyngedouw, E. (2003). Urban political ecology, justice and the politics of scale. Antipode, 34(4), 898-918.

Hirsch, P. (2016). The shifting regional geopolitics of Mekong dams. Political Geography, 51, 63-74.

Hommes, L., Boelens, R., \& Maat, H. (2016). Contested hydrosocial territories and disputed water governance: Struggles and competing claims over the Ilisu dam development in southeastern Turkey. Geoforum, 71, 9-20.

Hoogesteger, J., Boelens, R., \& Baud, M. (2016). Territorial pluralism: Water users' multi-scalar struggles against state ordering in Ecuador's highlands. Water International, 41(1), 91-106.

Illich, I. (1985). H2O and the waters of forgetfulness. Dallas: The Dallas Institute of Humanities and Culture.

Ioris, A. (2012). The geography of multiple scarcities: Urban development and water problems in Lima, Peru. Geoforum, 43, 612-622.

Ioris, A. (2016). Water scarcity and the exclusionary city: The struggle for water justice in Lima, Peru. Water International, 41(1), 125-139.

Jensen, C. B., \& Morita, A. (2016). Infrastructures as ontological experiments. Ethnos, $1-12$.

Jonas, A. (1994). The scale politics of spatiality. Environment and Planning D, 12(3), 257-264.

Kaika, M. (2006). Dams as Symbols of Modernization: The Urbanization of Nature Between Geographical Imagination and Materiality. Annals of the Association of American Geographers, 96, 276-301.

Kelly-Richards, S., \& Banister, J. M. (2016). A state of suspended animation: Urban sanitation and water access in Nogales, Sonora. Political Geography. http:// dx.doi.org/10.1016/j.polgeo.2015.04.002.

Larkin, B. (2013). The politics and poetics of infrastructure. Annual Review of Anthropology, 42, 327-343.

Lefebvre, H. (1991). The production of space. Oxford: Blackwell.

León, C. D. (2013). Plan de Acción para el Agua en la ciudad de Lima y Callao. Presentation LiWa Project [Online]. Available: http://www.lima-water.de/ documents/cleon_planaccion.pdf [Accessed 26.09.16].

Linton, J., \& Budds, J. (2014). The hydrosocial cycle: Defining and mobilizing a relational-dialectical approach to water. Geoforum, 57, 170-180.

Lynch, B. D. (2013). River of contention: Scarcity discourse and water competition in highland Peru. Georgia Journal of International \& Comparitive Law, 42, 69-92.

Maas, A., \& Anderson, R. (1978). And the desert shall rejoice: Conflict, growth, and justice in arid environments. Cambridge: MIT Press.

Meehan, K. (2013). Disciplining de facto development: Water theft and hydrosocial order in Tijuana. Environment and Planning D, 31(2), 319-336.

MINAGRI. (1995). Resolución administrativa No 119-95/AG-UAD.LC/ATDR.CHRL. Lima: Ministerio de Agricultura - Unidad Agraria Departamental Lima - Callao.

ANA (Autoridad Nacional del Agua), MINAGRI (2010). Reglamento de procedimientos administrativos para el otorgamiento de derechos de uso de agua (Lima).

Minca, C., Crampton, J. W., Bryan, J., Fall, J. J., Murphy, A. B., Paasi, A., et al. (2015). Review forum - reading stuart Elden's the birth of territory. Political Geography, 46, 93-101.

Miranda, L., Pfeffer, K., \& Baud, I. (2016). Unfolding urban geographies of waterrelated vulnerability and inequalities; recognizing risks in knowledge building in Lima, Peru. In A. Allen, S. Bell, P. Hofman, \& T. The (Eds.), Urban water trajectories. Dordrecht: Springer.

Molle, F., \& Berkoff, J. (2006). Cities versus agriculture: Revisiting intersectoral water transfers, potential gains and conflicts. Colombo: International Water Management Institute.

Molle, F., Mollinga, P., \& Wester, P. (2009). Hydraulic bureaucracies and the hydraulic mission: Flows of water, flows of power. Water Alternatives, 2, 328-349.
Mollinga, P. (2003). On the waterfront. Water distribution, technology and agrarian change on a South Indian canal irrigation system. Hyderabad: Orient Longman.

Moreno, J. C. A., \& Huerse, R. C. (2010). Diagnóstico socioeconómico de la cuenca del río Lurín, Centro Global para el Desarrollo y la Democracia (CGDD) (Lima).

Neue Züricher Zeitung. (13 November 1964). Pablo Boner - Ein Schweizer Pionier, 6. Morning Edition $N^{\circ} 4843$.

Noticias, R. P. P. (2012). Presidente inauguró represa de Huascacocha RPP Noticias, 29 June 2012.

Pasco-Font, R. U. (2015). Agua para Lima y Callao - Gestión de SEDAPAL. Presentation [Online]. Available: http://slideplayer.es/slide/9168157/ [Accessed 26.09.16].

Pfaffenberger, B. (1988). Fetishised objects and humanised nature: Towards an anthropology of technology. Man, New Series, 23(2), 236-252.

Ranganathan, M. (2014). Paying for pipes, claiming Citizenship: Political agency and water reforms at the urban periphery. International Journal of Urban and Regional Research, 38(2), 590-608.

Riveros, J. C., Germaná, C., \& Alvarez, C. (2014). Un Frágil Ciclo - agua, energía y población en Lima. Lima: WWF.

Roa-García, M. C. (2014). Equity, efficiency and sustainability in water allocation in the Andes: Trade-offs in a full world. Water Alternatives, 7(2), 298-319.

Rodríguez-De-Francisco, J. C., \& Boelens, R. (2016). PES hydrosocial territories: Deterritorialization and re-patterning of water control arenas in the Andean highlands. Water International, 41(1), 140-156.

Sanders, A. (2015). 'Wonderland' Peru - migration and the making of an Andean Switzerland. In P. Purtschert, \& H. Fischer-Tiné (Eds.), Colonial Switzerland: Rethinking colonialism from the margins (pp. 110-132). http://dx.doi.org/ 10.1057/9781137442741. Palgrave Macmillian UK.

Schütze, M., \& Robleto, G. (2009). Wasserversorgung in megacitys - Die Lebensader versiegt. Politische Ökologie, 114, 31-33.

SEDAPAL. (1998). El País de las Lagunas - Historia y Ecología de la Puna de Junín (Lima).

SEDAPAL. (2014). Plan Maestro de los Sistemas de Agua Potable y Alcantarillado (Lima).

Seemann, M. (2016). Inclusive recognition politics and the struggle over hydrosocial territories in two Bolivian highland communities. Water International, 41(1), $157-172$.

Seifert, R. (2009). Análisis de la situación del agua (cantidad y residual) en Lima Metropolitana. Lima: Proyecto LiWa/Zirn-Sedapal.

Showers, K. B. (2002). Water scarcity and urban Africa: An overview of urban-rural water Linkages. World Development, 30, 621-648.

Sosa, M., \& Zwarteveen, M. (2011). Acumulación a través del despojo: El caso de la gran minería en cajamarca. In R. Boelens, L. Cremers, \& M. Zwarteveen (Eds.), Justicia Hídrica: Acumulación, Conflicto y acción social. pp.381-392. Lima: IEP.

Steger, M. B., \& Paul, J. (2013). Levels of subjective globalization: Ideologies, imaginaries, ontologies. Perspectives on Global Development and Technology, 12(1-2), $17-40$.

Stoltenborg, D., \& Boelens, R. (2016). Disputes over land and water rights in gold mining: The case of Cerro de san pedro, Mexico. Water International, 41(3), 447-467.

Swyngedouw, E. (1997). Power, nature, and the city. The conquest of water and the political ecology of urbanization in Guayaquil, Ecuador: 1880-1990. Environment and Planning A, 29, 311-332.

Swyngedouw, E. (1999). Modernity and Hybridity: Nature, regeneracionismo, and the production of the spanish waterscape, 1890-1930. Annals of the American Academy of Political and Social Science, 89, 443-465.

Swyngedouw, E. (2004). Social power and the urbanization of water - flows of power New York: Oxford University Press.

Swyngedouw, E. (2009). The political economy and political ecology of the hydrosocial cycle. Universities Council on Water Resources - Journal of Contemporary Water Research \& Education, 56-60.

Swyngedouw, E. (2015). Urbanization and environmental Futures: Politicizing urban political ecologies. In T. Perreault, G. Bridge, \& J. McCarthy (Eds.), Handbook of political ecology (pp. 609-619). London and New York: Routledge.

Swyngedouw E. and Boelens R., (Forthcoming) And not a single injustice remains Hydro-territorial colonization and techno-political transformation in Spain. In: Boelens, R., Perreault, T., Vos, J., (Eds.) Water justice. Cambridge: Cambridge University Press.

Vos, H. de, Boelens, R., \& Bustamante, R. (2006). Formal law and local water control in the Andean region: A fiercely contested field. International Journal of Water Resources Development, 22(1), 37-48. http://dx.doi.org/10.1080/ 07900620500405049

Vos, J., \& Hinojosa, L. (2016). Virtual water trade and the contestation of hydrosocial territories. Water International, 41(1), 37-53.

Wachsmuth, D. (2012). Three Ecologies: Urban metabolism and the society-nature opposition. The Sociological Quarterly, 53, 506-523.

Winner, L. (1986). The whale and the reactor: A search for limits in an age of high technology. Chicago: Chicago University Press. 